\title{
Kreativitas Para Pekerja Kreatif Radio Gen 103.1 FM Surabaya Ditinjau Dari Peran Gaya Kepemimpinan Transformasional
}

\author{
Tri Siwi Agustina \\ Universitas Airlangga, Surabaya \\ Muhammad Novit Catur Putra \\ Universitas Airlangga, Surabaya
}

Email: siwi@feb.unair.ac.id

\begin{abstract}
Abstrak
Kreativitas karyawan merupakan faktor penting serta penentu dalam melakukan perubahan dan pengembangan bagi industri kreatif, agar dapat beradaptasi terhadap lingkungan sekitarnya. Salah satu faktor yang mendorong adanya kreativitas karyawan, adalah peran pemimpin yang bergaya transformational, karena diyakini mampu memberikan arahan dan motivasi kepada karyawan lebih terfokus dalam mencapai tujuan. Penelitian ini bertujuan mengganalisis pengaruh kepemimpinan transformasional terhadap kreativitas karyawan dengan fokus promosi dan creative process engagement sebagai mediator. Studi ini menggunakan pendekatan kuantitatif dengan jumlah sampel 41 orang menggunakan teknik purposive sampling. Untuk menguji hipotesis digunakan teknik analisis Smart PLS 3.2.9. Hasil penelitian menunjukkan kepemimpinan transformasional terbukti berpengaruh positif terhadap kreativitas karyawan. Fokus promosi terbukti berpengaruh positif terhadap kreativitas karyawan. Fokus promosi terbukti memediasi parsial pengaruh kepemimpinan transformasional terhadap kreativitas karyawan. Creative process engagement terbukti memediasi secara parsial pengaruh fokus promosi terhadap kreativitas karyawan
\end{abstract}

Kata Kunci: Creative Process Engagement, Fokus promosi, Kepemimpinan transformasional dan Kreativitas Karyawan

\section{Pendahuluan}

Surabaya sebagai kota terbesar kedua di Indonesia, telah memiliki industri penyiaran yang sangat berkembang. Hal ini terbukti dengan adanya 49 stasiun radio swasta yang ada di Surabaya. Setiap stasiun radio tersebut telah memiliki segmen pendengar serta mencoba mengambil target pendengar tertentu. (Jawa-timur.stt-mandala.web.id, 2021). Jumlah tersebut mengindikasikan bahwa radio masih menjadi pilihan masyarakat Surabaya sebagai media hiburan berbasis audio yang menyediakan berbagai macam konten seperti talkshow, kuis, berita, dan musik. Disisi lain banyaknya jumlah stasiun radio ini menjadikan persaingan industri radio semakin kompetitif sehingga setiap industri radio dituntut untuk mempertahankan perkembangan dan eksistensinya dengan menyajikan konten-konten yang kreatif dengan cara menawarkan nilai lain untuk mencapai pendengar yang semakin banyak dari tahun ke tahunnya.

Selain banyaknya stasiun radio yang ada, revolusi industri 4.0 membawa tantangan bagi industri radio. Di era internet yang bertumbuh pesat ini, selain kategori konten yang menarik dan beragam, platform pengusung juga sudah mulai banyak bermunculan. Dapat diartikan 


\section{Tri Siwi Agustina, Muhammad Novit Catur Putra}

bahwa persaingan dalam dunia radio tidak hanya bersaing dengan antar radio saja melainkan mulai bersaing juga dengan aplikasi atau platform streaming lainnya.

Pertama, aplikasi atau platform streaming yang dapat dengan mudah mengakses lagulagu apapun dan kapanpun yang disukai, seperti Spotify dan youtube music. Kedua, media sosial yang dapat memberikan berita atau informasi terbaru dan juga dapat mengirim salam atau pesan kepada orang lain dengan cepat dan mudah, seperti Instagram, Facebook, dan Whatsapp. Ketiga, kemunculan podcast pun bisa menjadi ancaman industri radio. Keberadan jenis program yang hampir sama dengan radio, podcast memiliki keunggulan dibandingkan radio seperti pendengar dapat memilih tema yang diinginkan, memutar secara berulang-ulang dan tanpa ada batasan waktu.

Di dalam industri radio, terdapat beberapa divisi yang karyawannya dituntut untuk memiliki kreatifitas yang tinggi agar dapat menyajikan konten-konten menarik dalam setiap programnya. Divisi-divisi tersebut diantara lain, yaitu program director, creative director, event promo, music director, announcer dan design graphic.

Penelitian ini dilakukan pada Radio Gen FM 103.1 Surabaya sebab dinilai salah satu radio swasta yang masih eksis di tengah ketatnya persaingan bisnis radio di Surabaya. Hasil wawancara dengan pimpinan Radio Gen FM 103.1 Surabaya pada bulan Januari 2021 menyatakan bahwa mengutip dari hasil survey Nielsen Listenership Study W1 pada tahun 2015, Radio Gen FM 103.1 Surabaya berada pada nomor 6 dari keseluruhan radio yang ada di Surabaya, dengan banyak pendengar sebanyak 358.000 orang. Selain itu berdasarkan lama waktu mendengarkan, radio ini menjadi nomor 2 di Surabaya, yaitu selama 8 jam 45 menit setiap harinya, dan dimana saja. Hal ini menunjukkan bahwa radio Radio Gen FM 103.1 Surabaya masih tetap mendapatkan perhatian para khalayak pendengar radio di Kota Surabaya.

Hasil wawancara pendahuluan dengan pengelola Radio Gen FM 103.1 Surabaya pada awal tahun 2021, narasumber juga menyampaikan bahwa dalam perusahaan yang berorientasi pada layanan seperti stasiun radio, setiap karyawan dituntut untuk dapat menghantarkan program yang menarik untuk mencapai kepuasaan pendengarnya. Proses kreativitas di Radio Gen FM 103.1 Surabaya dimulai dari rekrutmen yang ketat sampai memenuhi value yang dibutuhkan perusahaan. Berbagai project baru maupun evaluasi program rutin disampaikan pada acara formal melalui Forum Group Discusion (FGD) maupun non formal dapat setiap saat disampaikan pekerja kreatif di stasiun radio tersebut agar bisa dibahas lebih lanjut pada forum formal. Namun, kenyataannya tidak semua karyawan aktif dalam memberi ide, sebagian besar karyawan cenderung diam, enggan mengutarakan ide-idenya, malu mengutarakan dan lain-lain. Sehingga hanya karyawan tertentu dan cenderung lama yang menyampaikan aspirasi idenya baik di forum formal maupun nonformal. Penjelasan tersebut diatas mengindikasikan bahwa terdapat tantangan tersendiri dalam menggali kreativitas karyawan di Radio Gen FM 103.1 Surabaya.

Merujuk pada pendapat Anderson dkk (2014) kepemimpinan diyakini sebagai salah satu faktor personal yang mempengaruhi kreatifitas dan inovasi karyawan. Jaiswal \& Dhar (2015), Bai et al., (2016), Bin Saeed et al., (2019) Saleem \& Mahmood (2019) bahwa sosok pemimpin yang transformasional mampu memberikan masukan dan kesempatan karyawan untuk berkreasi serta mendukung penuh ide-ide karyawan untuk diwujudkan dalam realita.

Lebih lanjut, Van Dijk (2020) menambahkan bahwa untuk mengetahui pengaruh kepemimpinan transformasional terhadap kreativitas karyawan, penting untuk melibatkan fokus promosi. Fokus promosi adalah kesediaan karyawan untuk berbagi visi dengan pemimpinnya dan cenderung menciptakan dirinya lebih fokus pada hasil kerja yang positif.

Dalam upaya untuk memaksimalkan pengaruh fokus promosi terhadap kreativitas karyawan diperlukan adanya keterlibatan karyawan. Hal tersebut merujuk pada hasil penelitian 
Henker et al., (2015) bahwa keterlibatan karyawan dalam kreativitas (creative process engagament) terbukti mampu memediasi pengaruh fokus promosi pada kreativitas karyawan.

Berdasarkan penjelasan latar belakang di atas maka penulis tertarik untuk melakukan penelitian yang ingin mengetahui pengaruh gaya kepemimpinan transformasional terhadap kreativitas karyawan dimediasi oleh fokus promosi dan creative prosess engagement pada pekerja kreatif Radio Gen FM 103.1 Surabaya.

Penelitian ini terinspirasi dari penelitian sebelumnya yang dilakukan oleh Henker et al., (2015) dengan obyek penelitian 279 karyawan yang bekerja dalam bidang teknologi informasi, sumber daya manusia, penelitian dan pengembangan, dukungan teknis, manajemen eksekutif, strategi, dan hubungan masyarakat . Hasil penelitian menunjukkan kepemimpinan transformasional berpengaruh terhadap kreativitas. Fokus promosi terbukti mampu memediasi pengaruh kepemimpinan transformasional terhadap kreativitas serta creative process engagement terbukti mampu memediasi pengaruh fokus promosi terhadap kreativitas.

Apabila penelitian terdahulu tersebut dilakukan pada karyawan yang bekerja dalam bidang teknologi informasi, sumber daya manusia, penelitian dan pengembangan, dukungan teknis, manajemen eksekutif, strategi, dan hubungan masyarakat, maka penelitian ini dilakukan pada pekerja kreatif sebuah radio swasta di Surabaya. Hal itu didasari pada tuntutan kreativitas pada pekerja radio sangat menarik untuk diketahui ditengah persaingan bisnis radio yang sangat tinggi serta era disrupsi yang menghadirkan berbagai pilihan selain radio dalam menghibur masyarakat dan menyajikan kabar-kabar terkini.

Secara teoritis hasil penelitian ini diharapkan dapat memberikan sumbangan pemikiran bagi penelitian lebih lanjut mengenai kepemimpinan transformasional terhadap kreativitas karyawan dimediasi oleh fokus promosi dan creative prosess engagement pada karyawan. Secara praktis penelitian ini diharapkan dapat memberikan sumbangan pemikiran kepada pengeloa Radio Gen FM 103.1 Surabaya dalam mengoptimalkan kreativitas pekerja kreatifnya melalui gaya kepemimpinan transformational, fokus promosi dan creative prosess engagement.

\section{Landasan Teori dan Pengembangan Hipotesis}

Kepemimpinan transformasional adalah gaya kepemimpinan yang berorientasi pada hubungan, konvergensi antara atasan dan bawahan pada perilaku kepemimpinan atasan menjadi jauh lebih penting (Lee \& Carpenter, 2018). Gaya kepemimpinan transformasional memiliki dua karakteristik yang paling menonjol yaitu stimulasi intelektual dan pertimbangan individual (Bass \& Avolio, 1994). Stimulasi intelektual adalah upaya dari para pemimpin untuk memungkinkan pengikut menjadi ekspresif dan terbuka untuk lingkungan internal dan eksternal. Stimulasi intelektual mendorong pengikut untuk menjadi logis, rasional, dan cerdas untuk mengambil langkah (Dionne et al., 2004). Menurut Podsakoff (1990) terdapat enam dimensi kepemimpinan transformasional yaitu: Identifying and Articulating a Vision, Providing an Appropriate Model, Fostering the Acceptance of Group Goal, High Performance Expectations, Providing Individualized Support dan Intellectual Stimulation.

Kreativitas adalah kemampuan seseorang mengolah informasi berdasarkan pengetahuan, skill, dan pengalaman sebelumnya menjadi sebuah gagasan dan ide-ide baru Tingkat kreativitas seseorang dapat dilihat dengan originalitas hasil ciptaan gagasan, risk taking menghasilkan ide baru, mampu menghadapi kesulitan, dan menjadi panutan (Tierney \& Farmer ,2002). Terdapat lima faktor yang mendukung kreativitas, yakni: Organizational Climate, Leadership style, Organizational Culture, Resources \& skill dan Organizational Structure \& system (Tierney \& Farmer , 2002). Hennessey \& Amabile (2010) mengembangkan proses kreativitas menjadi lima langkah atau fase, yakni : (1) Penentuan masalah, fase ini 
meliputi proses pengakuan atau penyajian masalah yang akan dipecahkan (2) Identifikasi masalah, fase ini meliputi proses mengumpulkan informasi tentang masalah dari sumber eksternal (sumber tertulis, kolega dan teman) atau dari ingatan individu; (3) Pembangkitan ide/solusi, fase ini meliputi proses mengasilkan ide atau solusi dari pemasalahan yang muncul; (4) Identifikasi ide/solusi, fase ini meliputi proses identifikasi ide atau olusi mana yang paling memecahkan masalah dan memenuhi syarat (5) Penerapan solusi atau ide, fase ini meliputi proses penerapan ide atau solusi yang paling efektif.

Fokus promosi merupakan salah satu jenis dari regulatory focus. Konsep regulatory focus Pertama kali dikembangkan oleh Higgins (1997). Theory Regulatory Focus meneliti hubungan antara motivasi seseorang dan cara di mana tentang mencapai tujuan. Secara spesifik Higgins (1997) menyatakan bahwa seorang memiliki dua sistem self-regulation dasar. Pertama meregulasi pencapaian dari penghargaan dan memfokuskan pada tujuan promosi. Kedua meregulasi penjegahan hukuman atau konsekuensi negatif dan memfokuskan seseorang pada tujuan prevention. Fokus promosi dikaitkan dengan motivasi untuk mencapai keadaan akhir yang diinginkan, sedangkan prevetion focus dikaitkan dengan motivasi untuk menghindari akhir yang tidak diinginkan (Higgins 1997). Kedua fokus mengacu pada perilaku dan konsepsi diri yang diterapkan orang untuk menyelaraskan diri dengan tujuan atau standar yang tepat (Dijk et al., 2020; Higgins, 1997).

Fokus promosi telah terbukti bermanfaat untuk perilaku kreatif (Henker et al., 2015). Karyawan yang berfokus pada promosi harus lebih bersedia mengambil risiko kegagalan dan mencoba pendekatan kreatif, dan lebih bersemangat untuk menerapkan ide-ide kreatif. Menurut Neubert et al. (2008), fokus promosi dapat diukur oleh tiga dimensi, yaitu : Gains, Achievement dan Ideals.

Keterlibatan proses kreatif didefinisikan sebagai keterlibatan karyawan atau keterlibatan dalam proses yang terkait kreativitas (Henker et al., 2015). Zhang \& Bartol (2010) berpendapat bahwa terdapat tiga tahap dalam proses proses kreatif, yaitu: Identifikasi masalah, Pencarian informasi diikuti dengan pengkodean dan yang terakhir adalah menggenerasikan ide

Van Dijk et al., (2020), Bai et al., (2016) Henker et al., 2015; Jaiswal \& Dhar, 2015; Saleem \& Mahmood, 2019) menunjukan bahwa kepemimpinan transformasional berpengaruh secara positif terhadap kreativitas karyawan. Pemimpin transformasional menciptakan sebuah iklim yang mendukung untuk kreativitas. Dalam iklim ini, karyawan dapat mencoba pendekatan kreatif tanpa takut gagal. Kepemimpinan transformasional mendorong karyawan untuk menantang status quo dan mencoba pendekatan baru yang menumbuhkan kreativitas karyawan Berdasarkan alasan yang dijelaskan di atas, maka dirumuskan hipotesis sebagai berikut :

$\boldsymbol{H}_{1}$ : Kepemimpinan transformasional berpengaruh positif dan signifikan terhadap kreativitas karyawan

Untuk memahami mengapa kepemimpinan transformasional terkait dengan kreativitas karyawan, penting untuk menyelidiki mekanisme yang memediasi hubungan ini (Henker et al., 2015). Menurut Dijk et al. (2020) fokus promosi adalah salah satu dari dua regulatory yang didefinisikan dalam regulatory focus theory. Fokus promosi dikaitkan dengan motivasi untuk mencapai keadaan akhir yang diinginkan, sedangkan prevention focus dikaitkan dengan motivasi untuk menghindari akhir yang tidak diinginkan. Kedua fokus mengacu pada perilaku dan konsepsi diri yang diterapkan orang untuk menyelaraskan diri dengan tujuan atau standar yang tepat.

Fokus promosi erat kaitannya dengan kreativitas individu (Amabile et al., 1996). Dalam sebuah studi menunjukkan bahwa fokus promosi terkait dengan perilaku kreatif (Henker et al., 
2015; Neubert et al., 2008). Sejalan dengan penelitian sebelumnya, maka dirumuskan hipotesis sebagai berikut :

$\boldsymbol{H}_{2}$ : Fokus promosi berpengaruh positif dan signifikan pada kreativitas karyawan

Dijk et al., (2020) menyatakan bahwa kepemimpinan transformasional mendorong pertumbuhan dan perkembangan karyawan dan memenuhi syarat untuk mendorong fokus promosi Karyawan yang berbagi visi dengan pemimpinnya lebih mungkin untuk menciptakan diri yang ideal, dan karyawan dengan pemimpin transformasional diasumsikan lebih fokus pada hasil positif. Demikian pula, Henker et al., (2015) menyatakan bahwa pemimpin transformasional menyediakan lingkungan di mana karyawan tertarik dan fokus pada tugas, bukan masalah keamanan. Oleh karena itu, diusulkan agar pemimpin transformasional dapat mempengaruhi karyawan untuk mengaktifkan diri untuk menghasilkan hal - hal yang positif dan unggul. Berdasarkan pernyataan tersebut, maka dirumuskan:

$\boldsymbol{H}_{3}$ : Kepemimpinan transformasional berpengaruh terhadap kreativitas karyawan dengan mediasi fokus promosi

Keterlibatan dalam proses kreatif merupakan langkah pertama yang diperlukan menuju kreativitas (Gilson dan Shalley 2004; Shalley 1991, 1995). Karyawan yang berfokus pada promosi menunjukkan keterlibatan yang lebih tinggi dalam tahap pembuatan ide yang melibatkan pembuatan berbagai kemungkinan solusi dan alternatif Henker et al., (2015). Berdasarkan temuan di atas maka dapat dirumuskan hipotesis :

$\boldsymbol{H}_{4}$ : Fokus promosi berpengaruh terhadap kreativitas karyawan dengan mediasi Creative Process Engagement.

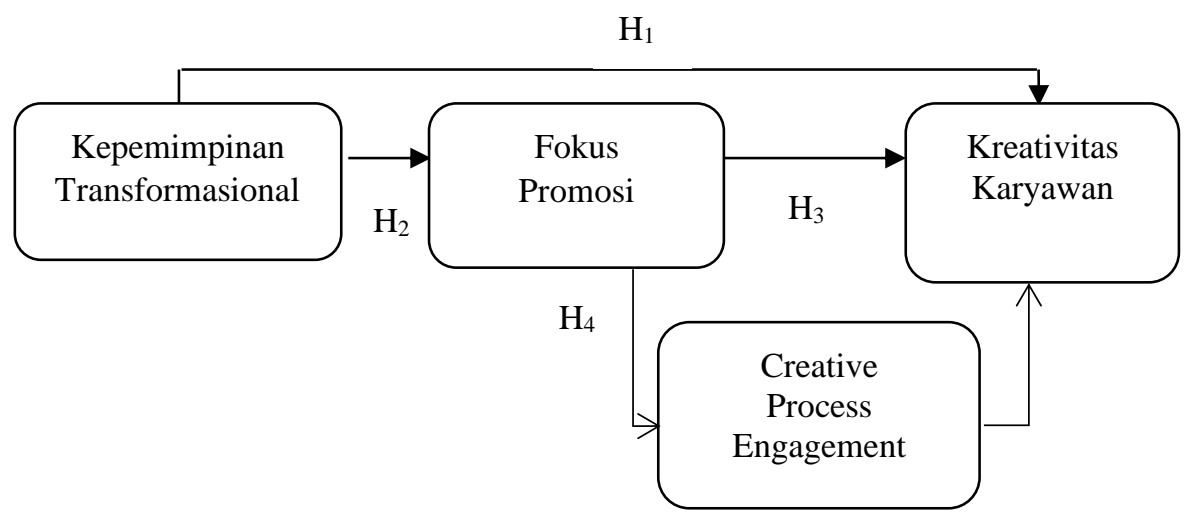

Gambar 1. Kerangka Konseptual

\section{Metode Penelitian}

Kepemimpinan transformasional didefinisi operasionalkan sebagai pandangan karyawan mengenai kemampuan pimpinan Radio Gen FM 103.1Surabaya dalam memotivasi dirinya dengan memberikan visi yang diinginkan, mengekspresikan harapan kinerja tinggi, memberikan dukungan individual, dan menantang karyawan untuk memikirkan menggantikan program lama dengan cara baru. Dimensi dan item pertanyaan pada kuesioner penelitian ini mengacu pada Podsakoff et al., (2006) yaitu: Identifying and Articulating a Vision, Providing an Appropriate Model, Fostering the Acceptance of Group Goal, High Performance Expectations, Providing Individualized Support dan Intellectual Stimulation 
Kreativitas karyawan dalam penelitian ini adalah kemampuan karyawan Radio Gen FM 103.1 Surabaya berinovasi untuk menciptakan program-program baru atau mengombinasi program lama menjadi bentuk program baru yang lebih berbeda dari sebelumnya dan dapat diterima pendengar. Indikator yang digunakan untuk kreativitas karyawan dalam penelitian ini didasarkan oleh penelitian Tierney \& Farmer (2002) meliputi: Organizational Climate, Leadership style, Organizational Culture, Resources \& skill dan Organizational Structure \& system

Pada penelitian ini, fokus promosi and creative process engagement merupakan variabel mediasi Fokus promosi dalam penelitian ini adalah kemauan pekerja kreatif di Radio Gen FM 103.1 Surabaya menunjukkan perilakunya yang mau untuk berkembang dan maju dengan melakukan inovasi. Terdapat tiga dimensi untuk mengukur fokus promosi menurut Neubert $e t$ al. (2008), meliputi: gains, achievement dan ideals.

Creative process engagement dalam penelitian ini adalah kemampuan pekerja kreatif di Radio Gen FM 103.1 Surabaya untuk problem identification, information search dan encoding, dan idea generation sebagai bentuk keterlibatan pada proses kreatif. Indikator creative process engagement didasarkan penelitian Zhang \& Bartol (2010), yaitu: problem identification, information search, dan idea generation. Keseluruan tanggapan dari responden dikategorikan dalam 5 skala Likert, yang terbentang dari Sangat Setuju (poin 5) hingga Sangat Tidak Setuju (poin 1)

Dalam penelitian ini, metode pengambilan sampel yang digunakan adalah nonprobability sampling dengan teknik purposive sampling, teknik ini peneliti memilih sampel berdasarkan ciri-ciri, sifat-sifat, atau karakteristik tertentu. Karakteristik sampel dalam penelitian ini adalah: karyawan yang pekerjaannya dituntut kreatif di Radio Gen FM 103.1 SurabayaFM di Surabaya. Berdasarkan syarat tersebut didapatkan responden dari 6 divisi yaitu program director, creative director, event promo, music director, announcer dan design graphic. Pekerja kreatif di 6 divisi tersebut meliputi : production, music, breakfast producer assistant, drive producer assistant, announcer, scheduler, News and Traffic Reporter integration, script writer, digital, Public Broadcasting Announcement, On Ground, Below The Line, Broadcast Staff, Messanger and Business Executive dengan jumlah keseluruhan adalah 41 orang. Oleh karena sudah memenuhi syarat karakteristik sampel maka keseluruhan jumlah tersebut diambil sebagai sampel (sampel jenuh).

Oleh karena jumlah sampel yang relatif kecil, maka hipotesis pada penelitian ini diuji dengan menggunakan teknik analisis Structural Equation Model-Partial Least Square (PLS).

\section{Pembahasan}

Karakteristik dari 41 orang pekerja kreatif di Radio Gen FM 103.1 Surabaya secara detil dikategorikan berdasarkan jenis kelamin, usia, pendidikan dan masa kerja pada Tabel 1 berikut:

Tabel 1. Karakteristik Responden

\begin{tabular}{|l|r|r|}
\hline Kategori & \multicolumn{1}{|c|}{ Frekuensi } & \multicolumn{1}{c|}{ Prosentase } \\
\hline Jenis Kelamin & 23 & $56,1 \%$ \\
\hline Laki-Laki & 18 & $43,9 \%$ \\
\hline Perempuan & & $4,9 \%$ \\
\hline Usia & 2 & $61 \%$ \\
\hline$<25$ Tahun & 25 & \\
\hline $25-30$ Tahun & & \\
\hline
\end{tabular}


Tri Siwi Agustina, Muhammad Novit Catur Putra

\begin{tabular}{|l|r|r|}
\hline $31-35$ Tahun & 12 & $29,3 \%$ \\
\hline$>35$ Tahun & 2 & $4,9 \%$ \\
\hline Masa Kerja & & \\
\hline$<1,5$ Tahun & 18 & $43,9 \%$ \\
\hline $2-3$ Tahun & 1 & $2,4 \%$ \\
\hline$>3$ Tahun & 22 & $53,7 \%$ \\
\hline Pendidikan & & \\
\hline D1/D2/D3/Sederajat & 19 & $46,3 \%$ \\
\hline D4/S1/Sederajat & 22 & $53,7 \%$ \\
\hline
\end{tabular}

Sumber : Data Olahan Peneliti, 2021

Untuk mencari nilai kategori masing-masing variabel, maka dilakukan dengan cara menjumlahkan jawaban dari masing-masing pertanyaan dan membaginya dengan jumlah pertanyaan yang ada. Kemudian dimasukkan ke dalam interval kelas, dengan rumus sebagai berikut:

$$
\text { Interval Kelas }=\frac{(\text { Rata }- \text { Rata Maksimum }- \text { Rata }- \text { Rata Minimum })}{\text { Jumlah Kelas }}=\frac{5-1}{5}=0,8
$$

Rata-rata maksimum diperoleh bila semua jawaban responden atas pertanyaan bernilai 5, dan rata-rata minimum tercapai bila semua jawaban responden atas pertanyaan bernilai 1 (proses ini digunakan untuk semua variabel), sehingga diperoleh range sebagai berikut: Interval 1,00 - 1,80 dikategorikan sangat rendah; Interval 1,81-2,60 dikategorikan rendah; Interval 2,61 - 3,40 dikategorikan cukup; Interval 3,41 hingga 4,20 dikategorikan tinggi dan ibterval 4,21 - 5,00 dikategorikan sangat tinggi. Sehingga hasil rata-rata jawaban responden per variabel dapat diketahui pada Tabel 2 berikut:

Tabel 2. Hasil Rata-rata Jawaban Responden Pada Masing-Masing Variabel

\begin{tabular}{|l|c|c|}
\hline \multicolumn{1}{|c|}{ Variabel } & Rerata & Kategori \\
\hline Kepemimpinan transformasional & 3.90 & Tinggi \\
\hline Kreativitas & 3.85 & Tinggi \\
\hline Fokus promosi & 4.03 & Tinggi \\
\hline Creative process engagement & 4.00 & Tinggi \\
\hline
\end{tabular}

Sumber : Data Olahan Peneliti, 2021

Berdasarkan tanggapan responden atas pernyataan pada variabel kepemimpinan transformasional menunjukkan nilai rerata 3.90 yang tergolong tinggi, hal ini menunjukkan bahwa pekerja kreatif di Radio Gen FM 103.1 Surabaya merasa pimpinannya dinilai mampu memotivasi dirinya dengan memberikan visi yang diinginkan, mengekspresikan harapan kinerja tinggi, memberikan dukungan individual, dan menantang karyawan untuk memikirkan pengembangan program.

Berdasarkan tanggapan responden atas pernyataan pada variabel kreativitas Karyawan menunjukkan nilai total rerata 3,85 yang masuk dalam kategori tinggi hal ini menunjukkan bahwa pekerja kreatif di Radio Gen FM 103.1 Surabaya memiliki kemampuan berinovasi yang tinggi untuk menciptakan program-program baru atau mengombinasi program lama menjadi bentuk program baru yang lebih berbeda dari sebelumnya dan dapat diterima pendengar. 
Nilai rerata total pada variabel fokus promosi adalah sebesar 4,03 yang masuk dalam kategori tinggi hal ini menunjukkan bahwa pekerja kreatif di Radio Gen FM 103.1 Surabaya menunjukkan perilaku yang tinggi untuk berkembang dan maju dengan melakukan inovasi.

Berdasarkan tanggapan responden atas pernyataan pada variabel Creative Process Engagement menunjukkan nilai total rerata sebesar 4,00 yang masuk dalam kategori tinggi hal ini menunjukkan bahwa pekerja kreatif di Radio Gen FM 103.1 Surabaya memiliki keterikatan yang tinggi dalam proses kreatif yang meliputi problem identification, information search and encoding, dan idea generation.

Langkah pertama untuk membuktikan hipotesis adalah mengetahui validitas dan reilabilitasnya. Pengukuran convergent validity menggunakan nilai outer loading dengan ketentuan nilai outer loading adalah lebih besar dari 0,5 . Sementara untuk penilaian construct validity digunakan nilai average variance extracted yang harus lebih besar dari 0,5 (Abdillah \& Jogiyanto, 2015). Diketahui pada Tabel 4, bahwa nilai loading faktor masing- masing variabel dalam penelitian ini telah memenuhi syarat karena telah lebih dari 0.5 sehingga dapat disimpulkan bahwa pengukuran variabel dalam model sudah memenuhi construct validity.

Evaluasi outer model selanjutnya adalah penilaian composite reliability untuk menguji reliabilitas masing-masing variabel dalam kerangka model penelitian. Suatu variabel dikatakan telah memenuhi composite reliability apabila nilai composite reliability serta nilai cronbach alpha lebih besar nilainya dari 0,7. (Abdillah \& Jogiyanto, 2015). Berdasarkan Tabel 4 dapat diketahui bahwa setiap variabel dalam model penelitian memiliki nilai composite reliability yang lebih besar dari 0,7. Sementara itu, untuk nilai cronbach alpha juga diperoleh nilai yang kesemuanya lebih besar dari 0,60. Mengacu pada hasil evaluasi ini, maka dapat disimpulkan bahwa pada masing-masing variabel penelitian telah memenuhi composite reliability.

Table 4. Nilai Cronbach's Alpha dan Nilai Composite Reliability

\begin{tabular}{|l|c|c|c|}
\hline \multicolumn{1}{|c|}{ Variabel } & $\begin{array}{c}\text { Cronbach's } \\
\text { Alpha }\end{array}$ & $\begin{array}{c}\text { Composite } \\
\text { Reliability }\end{array}$ & AVE \\
\hline $\begin{array}{l}\text { Kepemimpinan } \\
\text { transformasional }\end{array}$ & 0.976 & 0.981 & 0.894 \\
\hline Fokus promosi & 0.952 & 0.969 & 0.912 \\
\hline Creative process engagement & 0.954 & 0.970 & 0.916 \\
\hline Kreativitas & 0.979 & 0.982 & 0.855 \\
\hline
\end{tabular}

Sumber : Data Olahan Peneliti, 2021

Analisis data yang dipergunakan dalam penelitian ini adalah metode statistik SEM Partial Least Square (PLS) menggunakan Smart PLS 3.2.9 yang terdiri atas tahapan evaluasi outer dan inner model. Model struktural partial least square penelitian disusun berdasarkan pengukuran second order pada semua variabel yang dipergunakan. Penjelasan lengkap atas hasil analisis Partial Least Square dari model penelitian dapat dijelaskan sebagai berikut: 


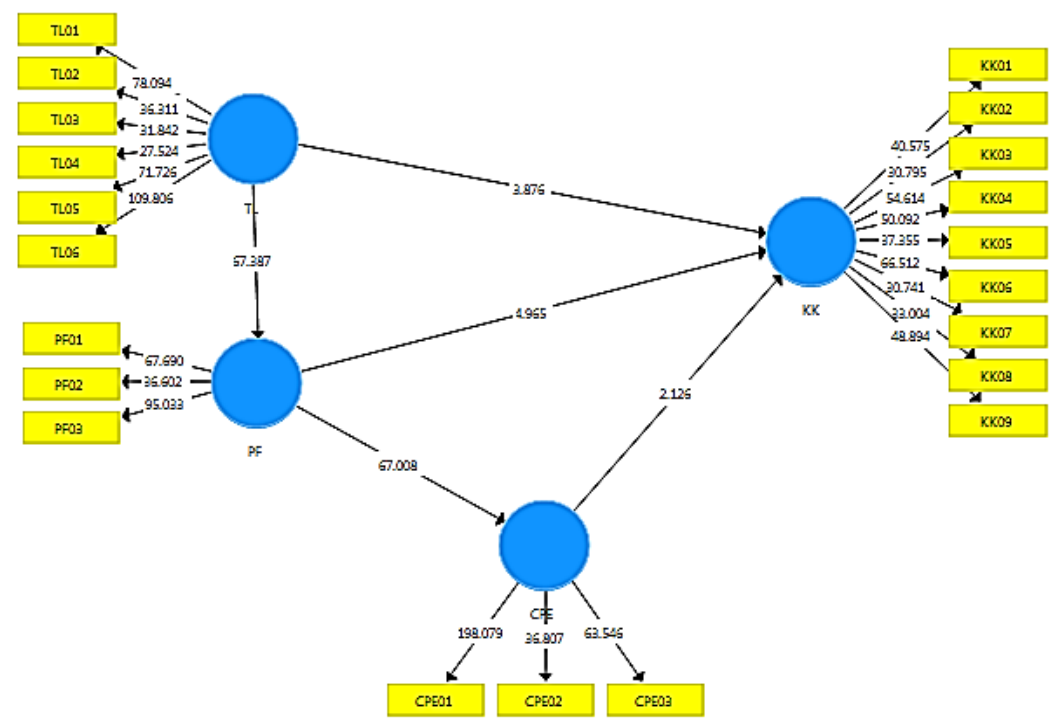

Gambar 2 : Hasil Olah Statistik (2021)

Evaluasi inner model model struktural partial least square dilakukan berdasarkan pada hasil estimasi bootstrapping pada model yang disusun. Pada evaluasi inner model akan dijelaskan uraian pada hasil $R$-square, dan pengujian hipotesis penelitian yang dikembangkan dalam model struktural. Hasil dari estimasi bootstrapping model struktural dengan Smart PLS 3.2.9 adalah sebagai berikut:

Tabel 5. Nilai R-square

\begin{tabular}{|l|c|c|}
\hline \multicolumn{1}{|c|}{ Variable } & R Square & R Square adjusted \\
\hline Fokus promosi & 0.887 & 0.884 \\
\hline Creative process engagement & 0.914 & 0.912 \\
\hline Kreativitas Karyawan & 0.972 & 0.970 \\
\hline
\end{tabular}

Sumber : Data Olahan Peneliti, 2021

Nilai $R$-square menjelaskan bahwa prosentase keberagaman tanggapan variabel yang dikemukakan oleh pekerja kreatif Radio Gen FM 103.1 Surabaya sebesar 97,2\% dalam menjelaskan variabel kreativitas karyawan, sedangkan sisanya 2,8\% dijelaskan oleh variabel lain diluar model.

Berikutnya dilakukan analisis dengan melihat nilai $R$-square yang merupakan uji goodness-fit model. Tujuan melakukan pengujian Goodness of Fit Index (GoF) adalah untuk memvalidasi performa gabungan antara model pengukuran (outer model) dan model struktural (inner model) yang diperoleh melalui perhitungan sebagai berikut:

Keterangan :

$$
\begin{aligned}
& \text { GoF }=\sqrt{A V E x R^{2}} \\
& \text { GoF }=\sqrt{0,6805 \times 0,263} \\
& \text { GoF }=\sqrt{0,1789} \\
& \text { GoF }=0,423(\text { GoF large })
\end{aligned}
$$

$$
\begin{aligned}
& \mathrm{AVE}=(0,894+0,912+0,916+0,855) / 4=0,6805 \\
& \mathrm{R}^{2}=(0,887 \times 0,914 \times 0,972) / 3=0,263
\end{aligned}
$$


Hasil perhitungan Goodness of Fit Index (GoF) menunjukkan nilai 0,423. Menurut Ghozali \& Latan (2012) kriteria nilai GoF adalah 0,10 (GoF small), 0,25 (GoF medium), dan 0,36 (GoF large), maka dapat disimpulkan bahwa performa gabungan antara model pengukuran (outer model) dan model struktural (inner model) secara keseluruhan adalah cukup baik karena nilai Goodness of Fit Index (GoF) lebih dari 0,36 (GoF large).

Evaluasi inner weight dipergunakan untuk melakukan pengujian atas hipotesis penelitian yang uraiannya nampak pada Tabel 6 berikut:

Tabel 6. Hasil Pengaruh Langsung dan Tidak Langsung

\begin{tabular}{|l|c|c|c|c|}
\hline \multicolumn{1}{|c|}{ Hipotesis } & $\begin{array}{c}\text { Sampel } \\
\text { Orisinal }\end{array}$ & $\begin{array}{c}\text { T- } \\
\text { statistik }\end{array}$ & p-value & Deksripsi \\
\hline $\begin{array}{l}\text { Kepemimpinan Transformasional -> } \\
\text { Kreativitas Karyawan }\end{array}$ & 0.345 & 3.676 & 0.000 & Signifikan \\
\hline Fokus promosi -> Kreativitas Karyawan & 0.463 & 4.965 & 0.000 & Signifikan \\
\hline $\begin{array}{l}\text { Kepemimpinan Transformasional -> } \\
\text { Fokus promosi -> Kreativitas Karyawan }\end{array}$ & 0.436 & 4.906 & 0.000 & Signifikan \\
\hline $\begin{array}{l}\text { Fokus promosi -> Creative Prosess } \\
\text { Engagement }->\text { Kreativitas Karyawan }\end{array}$ & 0.186 & 2.120 & 0.035 & Signifikan \\
\hline
\end{tabular}

Sumber : Data Olahan Peneliti, 2021

Pengujian hipotesis menggunakan metode Bootstrapping. Hipotesis diterima jika tvalues $0,05(\alpha 5 \%)$ dan/atau t-statistic $>1,65$. Berdasarkan Tabel 6 di atas, dapat diintepretasikan sebagai berikut:

Hasil perhitungan pengaruh kepemimpinan transformasional terhadap kreativitas karyawan menunjukkan nilai koefisien parameter sebesar 0,345 (positif) dengan $\mathrm{T}$ statistik 3,676>1,65 dan $p$-value 0,000 < 0,05 (signfikan). Berdasarkan hasil pengujian ini menjelaskan bahwa variabel Kepemimpinan transformasional berpengaruh positif dan signifikan terhadap kreativitas karyawan. Dengan demikian, hipotesis yang menyatakan Kepemimpinan transformasional berpengaruh positif dan signifikan terhadap kreativitas karyawan, diterima (H1).

Hasil perhitungan terhadap koefisien parameter pengaruh fokus promosi terhadap kreativitas karyawan menunjukkan nilai 0,463 (positif) dengan nilai T statistik 4,965 > 1,65 dan $p$-value $0,000<0,05$ signifikan). Berdasarkan hasil pengujian ini menjelaskan bahwa variabel fokus promosi berpengaruh positif dan signifikan terhadap kreativitas karyawan. Dengan demikian, hipotesis yang menyatakan fokus promosi berpengaruh positif dan signifikan terhadap kreativitas karyawan, diterima $\left(\mathbf{H}_{2}\right)$.

Hasil perhitungan pengaruh tidak langsung pengaruh kepemimpinan transformasional terhadap kreativitas karyawan melalui fokus promosi menunjukkan nilai koefisien parameter 0,436 (positif) dengan nilai T statistik 4,906 > 1,65 dan $p$-value 0,000 <0,05 (signifikan). Dengan demikian, hipotesis yang menyatakan bahwa Kepemimpinan transformasional berpengaruh positif dan signifikan terhadap kreativitas karyawan dengan fokus promosi sebagai pemediasi, diterima $\left(\mathbf{H}_{3}\right)$. Untuk mengetahui efek mediasi menggunakan uji VAF diperoleh nilai sebesar 55,83\%. Dengan hasil seperti ini, maka variabel fokus promosi dikategorikan partial mediation.

Hasil perhitungan pengaruh tidak langsung pengaruh fokus promosi dan kreativitas karyawan melalui Creative Prosess Engagement menunjukkan nilai koefisien parameter 0,186 (positif) dengan nilai T statistik 2,120 > 1,65 dan p-value 0,035 $<0,05$ (signifikan). Dengan demikian, hipotesis yang menyatakan bahwa fokus promosi berpengaruh positif dan signifikan 
terhadap kreativitas karyawan dengan Creative Prosess Engagement sebagai pemediasi, diterima ( $\left.\mathbf{H}_{4}\right)$. Untuk mengetahui efek mediasi menggunakan uji VAF diperoleh nilai sebesar 28,66\%. Dengan hasil seperti ini, maka variabel Creative Prosess Engagement dikategorikan partial mediation antara fokus promosi terhadap kreativitas karyawan.

\section{Pembahasan}

\section{Pengaruh Kepemimpinan transformasional terhadap Kreativitas Karyawan}

Kepemimpinan transformasional terbukti berpengaruh positif dan signifikan terhadap kreativitas karyawan. Hasil ini menjelaskan bahwa untuk dapat mendorong kreativias karyawan di Radio Gen FM 103.1 SurabayaFM Surabaya dibutuhkan gaya kepemimpinan yang mampu mengubah dan memotivasi para pengikut melalui enam dimensi yaitu identifying and articulating a vision, providing an appropriate model, fostering the acceptance of group goals, high performance expectations, providing individualized support, dan intellectual stimulation.

Hasil analisis deskriptif pada variabel kepemimpinan transformasional menunjukkan rata-rata nilai sebesar 3,90 yang tergolong dalam kategori tinggi dengan rerata tertinggi pada indicator yang menyatakan bahwa pimpinan memiliki pemahaman yang jelas tentang kemana tujuan perusahaan, hasil tersebut dapat dimaknai bahwa secara umum karyawan Radio Gen FM 103.1 SurabayaFM Surabaya mempersepsikan bahwa pimpinan telah memberikan penjelasan dan arahan tentang visi-misi Radio Gen FM 103.1 SurabayaFM Surabaya dalam beberapa tahun mendatang. Arahan yang diberikan dapat mudah dipahami sehingga mempermudah dalam mewujudkan ide - ide kreatif dalam bekerja. Pernyataan ini sejalan dengan pendapat dari (Henker et al., 2015) bahwa Pemimpin transformasional memperkuat konsep diri kreatif dari karyawan.

Aktivitas kreativitas di radio, dapat digambarkan sebagai berikut : pertama, didalam divisi program director, mempunyai tugas dalam membuat tema atau warna radio yang akan disiarkan. Kedua, divisi creative director yang memberikan uraian konsep yang telah diberikan menjadikan program-program yang lebih spesifik untuk disiarkan . Ketiga, divisi event promo bertugas memikirkan konsep-konsep acara yang akan diselenggarakan perusahaan dan mencari peluang untuk bekerja sama dengan pihak eksternal dengan tujuan branding. Keempat, divisi music director yang membuat dan mengatur chart music yang akan disukai pendengarnya. Kelima, divisi announcer yang bertugas mengimplementasikan konsep atau ide yang telah dibuat agar tersampaikan dengan baik. Terakhir, design graphic bertanggung jawab dalam pembuatan desain-desain menarik dan juga bertugas mendokumentasikan setiap acara yang akhirnya akan dipublikasikan di media sosial yang dimiliki perusahaan. Oleh karena itu, dari tugas dalam divisi tersebut creativity sangat penting guna mempertahankan dan menambah nilai dalam suatu industri radio.

\section{Pengaruh Fokus promosi Terhadap Kreativitas Karyawan}

Hasil pengujian hipotesis kedua menyatakan bahwa fokus promosi terbukti berpengaruh positif dan signifikan terhadap kreativitas karyawan, hal tersebut dapat dimaknai bahwa karyawan yang lebih terfokus dalam mencapai tujuan yang berhubungan dengan kemajuan dan prestasi atau fokus promosi akan mampu mengaplikasikan ide-ide yang ada dalam dirinya

Berdasatkan Tabel dapat diketahui bahwa rerata fokus promosi tergolong tinggi dan rerata kreativitas karyawan juga tergolong tinggi. Hasil analisis deskriptif menunjukkan karyawan Radio Gen FM 103.1 SurabayaFM Surabaya menunjukkan perilaku yang tinggi untuk berkembang dan maju dengan melakukan inovasi. Hal ini ditunjukkan dengan nilai ratarata total yaitu sebesar 4,03 yang masuk dalam kategori tinggi. Berdasarkan analisis indikator 
dari fokus promosi yang memiliki nilai rerata jawaban responden tertinggi adalah "Prioritas pekerjaan saya dipengaruhi oleh gambaran yang jelas tentang apa yang saya inginkan." dengan rerata jawaban sebesar 4,24. Hal tersebut menjelaskan bahwa dalam penelitian ini, karyawan Radio Gen FM 103.1 SurabayaFM Surabaya cenderung memperioritaskan pekerjaan yang relevan dengan keinginannya.

Isyarat situasional yang menekankan kebutuhan pengasuhan, pencapaian cita-cita, dan potensi keuntungan cenderung mendorong pola pikir fokus promosi. Dimensi ketiga dari fokus promosi yaitu Ideals paling kuat dalam meningkatkan kreativitas karyawan. Menurut Neubert et al. (2008), karyawan yang fokus pada penapaian cita-cita maka akan menghabiskan banyak waktu untuk memikirkan cara untuk memenuhi keinginannya, memiliki gambaran yang jelas tentang hal yang diinginkan, dan dimotivasi oleh harapan dan keinginannya. Sejalan pendapat Higgins (1997), fokus promosi dikaitkan dengan motivasi untuk mencapai keadaan akhir yang diinginkan. Menurut Dijk et al. (2020), fokus promosi mengacu pada perilaku dan konsepsi diri yang diterapkan orang untuk menyelaraskan diri dengan tujuan atau standar yang tepat.

Hasil penelitan ini didukung dengan penelitian terdahulu Neubert et al. (2008) bahwa fokus promosi berpengaruh positif dan signifikan terhadap kreativitas karyawan. Didukung penelitian Henker et al. (2015), dalam konteks kreativitas, fokus promosi sangat relevan karena fokus promosi dikaitkan dengan keinginan dan pengambilan risiko. Karyawan yang berfokus pada promosi lebih bersedia mengambil risiko kegagalan dan mencoba pendekatan kreatif, dan lebih bersemangat untuk mempraktikkan ide-ide kreatif.

Sejalan pendapat Higgins (1997) dan Dijk et al. (2020) fokus promosi adalah suatu bagian yang relevan terhadap kreativitas karena fokus promosi berhubungan dengan keinginan atau hasrat dan pekerjaan yang berisiko dan hal tersebut mempunyai dampak yang positif bagi individu yang bergerak di bidang kreativitas. Adanya bagian yang relevan tersebut nantinya akan berimbas pada karakter setiap individu yang mengalami fokus promosi dan yang bergerak di bidang kreativitas, hal itu dapat memicu hasrat individu untuk menuangkan pemikirannya untuk berpikir lebih terbuka dan kreatif.

\section{Pengaruh Kepemimpinan transformasional Terhadap Kreativitas Karyawan dengan Fokus promosi Sebagai Mediasi}

Kepemimpinan transformasional memiliki pengaruh positif dan signifikan terhadap kreativitas karyawan dengan fokus promosi sebagai pemediasi. Hasil penelitian ini sejalan dengan penelitian Henker et al. (2015), bahwa pemimpin transformasional dapat meningkatkan kreativitas karyawan baik secara langsung maupun tidak langsung dengan mendorong karyawan lebih terfokus dalam mencapai tujuan yang berhubungan dengan kemajuan dan prestasi dan mendorong karyawan untuk sering mendiskusikan ide-ide terbaru.

Jenis mediasi fokus promosi adalah parsial, sehingga dapat diartikan bahwa untuk meningkatkan kreatitas pekerja kreatif Radio Gen FM 103.1 Surabaya FM Surabaya, tidak cukup hanya bergantung pada peran pemimpin yang memberikan kepercayaan, kekaguman, kesetiaan, penghormatan, arahan dan motivasi. Upaya tersebut perlu adanya fokus promosi, karena dengan fokus promosi, karyawan dapat lebih fokus dalam mencapai tujuan yang berhubungan dengan kemajuan dan prestasi, sehingga berdampak pada kemampuan karyawan mengaplikasikan ide-ide kreatifnya. Selain itu karyawan juga memiliki keberanian mengambil risiko dan tidak takut gagal karena pemimpinnya tetap mengapresiasi ide - ide kreatifnya apabila ide tersebut tidak berhasil. Kondisi demikian memotivasi karyawan untuk tetap menemukan ide-ide kreatif. 


\section{Pengaruh Fokus promosi Terhadap Kreativitas Karyawan dengan Creative Process Engagement sebagai mediasi}

Berdasarkan hasil penelitian menunjukkan bahwa fokus promosi berpengaruh positif dan signifikan terhadap kreativitas karyawan dengan Creative Process Engagement sebagai pemediasi. Hasil penelitian ini sejalan dengan pendapat Henker et al. (2015), bahwa mayoritas penelitian kreativitas berfokus pada hasil kreativitas, namun hasil kreativitas idealnya didahului oleh Creative Process Engagement (keterlibatan dalam proses kreatif). Keterlibatan dalam proses kreatif merupakan langkah pertama yang diperlukan menuju kreativitas.

Jenis mediasi dari Creative Process Engagement dikategorikan partial mediation sehingga dapat dimaknai bahwa untuk meningkatkan kreatitas pekerja kreatif Radio Gen FM 103.1 Surabaya, tidak cukup hanya berfokus pada promotion namun juga perlu didukung adanya Creative Process Engagement.

Nilai rerata creative process engagement yang menunjukan bahwa pekerja kreatif Radio Gen FM 103.1 Surabaya memiliki perilaku yang tinggi dalam keterlibatan proses kreatif. Berdasarkan analisis indikator dari yang memiliki nilai rerata jawaban responden tertinggi adalah karyawan berfikir tentang permasalahan dari berbagai perspektif, dengan rerata jawaban sebesar 4,27. Hal tersebut menjelaskan bahwa dalam penelitian ini, pekerja kreatif Radio Gen FM 103.1 Surabaya mengupayakan berbagai macam sudut pandang dalam mengidentifikasi masalah sehingga memungkinkan mereka untuk mengembangkan pemecahan masalah yang lebih akurat dan lebih orisinal.

Hasil penelitian ini sejalan dengan pendapat Higgins (1997) bahwa inti dari ciri individu yang sedang dalam fokus promosi adalah individu yang mempunyai ide atau gagasan yang luas dan juga berorientasi. Fokus promosi juga dapat membantu individu dalam menemukan suatu ide atau gagasan yang baru, karena individu yang sedang dalam fokus promosi tidak mempunyai batasan berpikir, individu akan melakukan segalanya untuk dapat berkembang dan berinovasi sehingga dapat mendorong munculnya suatu ide dan gagasan yang baru.

Lebih lanjut Higgins (1997) menjelaskan bahwa individu yang berada dalam fokus promosi mencoba untuk melakukan pendekatan yang berbeda dengan maksud untuk mencari pendekatan yang bisa membawa individu lebih dekat terhadap tujuan akhirnya. Zhang \& Bartol (2010) menambahkan bahwa karyawan yang berfokus pada promosi menunjukkan keterlibatan yang lebih tinggi dalam tahap pembuatan ide yang melibatkan pembuatan berbagai kemungkinan solusi dan alternatif.

\section{Daftar Pustaka}

Abdillah, W., \& Jogiyanto, H. (2015). Partial Least Square (PLS). Penerbit Andi, Yogyakarta. Amabile, T. M., Conti, R., Coon, H., Lazenby, J., \& Herron, M. (1996). Assessing the Work Environment for Creativity. The Academy OfManagement Journal, 39(5), 1154-1184.

Bai, Y., Lin, L., \& Li, P. P. (2016). How to enable kreativitas in a team context: A cross-level mediating process of Kepemimpinan transformasional. Journal of Business Research, 69(9), 3240-3250. https://doi.org/10.1016/j.jbusres.2016.02.025

Bin Saeed, B., Afsar, B., Shahjehan, A., \& Imad Shah, S. (2019). Does Kepemimpinan transformasional foster innovative work behavior? The roles of psychological empowerment, intrinsic motivation, and creative process engagement. Economic Research-Ekonomska Istrazivanja , $32(1), \quad 254-281$. https://doi.org/10.1080/1331677X.2018.1556108

Brockner, J., \& Higgins, E. T. (2001). Regulatory focus theory: Implications for the study of emotions at work. Organizational Behavior and Human Decision Processes, 86(1), 3566. https://doi.org/10.1006/obhd.2001.2972 
Ghozali, I., \& Latan, H. (2012). Partial Least Square : Konsep, Teknik dan Aplikasi. SmartPLS 2.0 M3. Badan Penerbit Universitas Diponegoro.

Henker, N., Sonnentag, S., \& Unger, D. (2015). Kepemimpinan transformasional and Kreativitas: The Mediating Role of Fokus promosi and Creative Process Engagement. Journal of Business and Psychology, 30(2), 235-247. https://doi.org/10.1007/s10869014-9348-7

Jaiswal, N. K., \& Dhar, R. L. (2015). Kepemimpinan transformasional, innovation climate, creative self-efficacy and kreativitas: A multilevel study. International Journal of Hospitality Management, 51, 30-41. https://doi.org/10.1016/j.ijhm.2015.07.002

Jawa-timur.stt-mandala.web.id. (2021). Daftar stasiun radio di Jawa Timur.

Neubert, M. J., Kacmar, K. M., Carlson, D. S., Chonko, L. B., \& Roberts, J. A. (2008). Regulatory Focus as a Mediator of the Influence of Initiating Structure and Servant Leadership on Employee Behavior. Journal of Applied Psychology, 93(6), 1220-1233. https://doi.org/10.1037/a0012695

Podsakoff, M., Mackenzie, S. B., \& Moorman, H. (2006). <1990 PODSAKOFF Kepemimpinan transformasional OCB Questionnaire.pdf>. Leadership Quarterly, 2, 107-142.

Podsakoff, M., Mackenzie, S. B., Moorman, H., \& Fetter, R. (1990). Transformational Leader Behaviors And Their Effects On Followers' Trust In Leader, Satisfaction, And Organizational Citizenship Behaviors. Leadership Quarterly, 1(2), 107-142.

Saleem, M., \& Mahmood, F. (2019). Kepemimpinan transformasional and Employees' Creativity: A Multi-Mediation Model. Journal of Management and Research, 5(1), 1-21. https://doi.org/10.29145/jmr/51/0501005

Shin, S. J. A. E., \& Zhou, J. (2003). Kepemimpinan transformasional, Conservation, and Creativity: Evidence From Korea. Academy of Management Journal, 46(6), 703-714.

Tierney, P., \& Farmer, S. M. (2002). Creative Self-Efficacy: Its Potential Antecedents and Relationship to Creative Performance. The Academy of Management Journal, 45(6), 1137-1148.

Van Dijk, D., Kark, R., Matta, F., \& Johnson, R. E. (2020). Correction to: Collective aspirations: Collective regulatory focus as a mediator between transformational and transactional leadership and team creativity (Journal of Business and Psychology, (2020), 10.1007/s10869-020-09692-6). Journal of Business and Psychology. https://doi.org/10.1007/s10869-020-09699-z

Zhang, X., \& Bartol, K. M. (2010). Linking Empowering Leadership And Kreativitas: The Influence Of Psychological Empowerment, Intrinsic Motivation, And Creative Process Engagement. Academy Of Management Journal, 53(1), 107-128. 